\title{
UJI AKTIVITAS ANTIBAKTERI EKSTRAK ETANOL DAUN PIRDOT (Saurauia vulcani Korth.) TERHADAP BAKTERI Salmonella thypi
}

\section{ANTIBACTERIAL ACTIVITY TEST OF ETHANOL EXTRACT OF PIRDOT LEAF (Saurauia vulcani Korth.) AGAINST BACTERIA Salmonella thypi}

\author{
Debi Dinha Octora*, Romauli Anna Teresia Marbun, Rahmadona Koto \\ Institut Kesehatan Medistra Lubuk Pakam \\ Jalan Sudirman No. 38 Lubuk Pakam Indonesia, 20152 \\ e-mail: debi.d.o.sitepu@gmail.com \\ DOI : https://doi.org/10.35451/jfm.v2i1.286
}

\begin{abstract}
Indonesia is known for the many plants that are used as traditional medicine for disease prevention, including the leaves of the pirdot (Saurauia vulcani Korth) family Actinidiaceae. This study aims to determine the antibacterial activity of ethanol extract of pirdot leaves (Saurauia vulcani Korth). The results of the characterization of pirdot leaf simplicia powder were obtained $3.99 \%$ water content, water soluble extract $12.15 \%$, ethanol soluble extract $8.89 \%$, total ash content $9.97 \%$, insoluble ash content in acids $3.17 \%$. The results of phytochemical screening tests contained the chemical compounds of steroids / triterpenoids, flavonoids, glycosides, tannins and saponins. Ethanol extract of pirdot leaf has antibacterial activity against Salmonella typhi bacteria. The treatment consisted of 4 concentrations, pirdot leaf extract with 3 repetitions, each blank (DMSO), $50 \mathrm{mg} / \mathrm{ml}, 100 \mathrm{mg} / \mathrm{ml}, 150 \mathrm{mg} / \mathrm{ml}, 200 \mathrm{mg} / \mathrm{ml}$. After that, it was incubated for 24 hours at 37oC. Inhibition zone diameter observations were made using calipers. The results obtained showed that administration of pirdot leaf extract at concentrations of $50 \mathrm{mg} / \mathrm{ml}, 100 \mathrm{mg} /$ $\mathrm{ml}, 150 \mathrm{mg} / \mathrm{ml}$ and $200 \mathrm{mg} / \mathrm{ml}$ can inhibit the growth of Salmonella typhi bacteria. The results of the antibacterial activity test of pirdot leaf ethanol extract against Salmonella typhi bacteria obtained the highest inhibitory concentration of $200 \mathrm{mg} / \mathrm{ml}$ with a diameter of $20.48 \mathrm{~mm}$.
\end{abstract}

Keywords: Ethanol Extract of Pirdot Leaves (Saurauia vulcani Korth), Salmonella thypi and Antibacteria

\section{PENDAHULUAN}

Demam thypoid yang disebabkan oleh bakteri Salmonella typhi merupakan masalah kesehatan masyarakat yang penting karena penyebarannya berkaitan erat dengan urbanisasi, kepadatan 
penduduk, kesehatan lingkungan, sumber air dan sanitasi yang buruk. WHO (World Health Organization) memperkirakan terdapat sekitar 17 juta kematian terjadi tiap tahun akibat penyakit ini.Asia menempati urutan tertinggi pada kasus thypoid ini, dan terdapat 13 juta kasus terjadi tiap tahunnya.Di Indonesia diperkirakan antara 800-100.000 orang yang terkena penyakit demam thypoid sepanjang tahun.Kasus thypoid di derita oleh anak-anak sebesar $91 \%$ berusia 3-19 tahun dengan angka kematian 20.000 pertahunnya (WHO, 2003). Demam thypoid menjadi masalah kesehatan masyarakat yang penting karena penyebarannya berkaitan erat dengan urbanisasi, kepadatan penduduk, kesehatan lingkungan, sumber air dan sanitasi yang buruk serta standar kebersihan industrri pengolahan makanan yang masih rendah. Di Indonesia angka kejadian kasus demam thypoid diperkirakan rata-rata 900.000 kasus pertahun dengan lebih dari 20.000 kematian (Riskesdas, 2007). Insidensi demam tifoid bervariasi di setiap daerah dan biasanya terkait dengan sanitasi lingkungan. Di daerah rural seperti Jawa Barat ditemukan 157 kasus per 100.000 penduduk, sedangkan di daerah urban ditemukan 760-810 per 100.000 penduduk (Widodo, 2009).

Saat ini banyak bakteri yang resisten terhadap berbagai antibiotik, salah satunya adalah Salmonella typhi. Selama 10 tahun terakhir, Salmonella typhi dengan plasmid-encoded resisten terhadap antibiotik kloramfenikol yang sebelumnya adalah drug of choice untuk demam tifoid. Resistensi ini terjadi di negara Indian subcontinent, Asia Tenggara, dan Afrika (Gama, 2012). Banyaknya kejadian resistensi terhadap antibiotik menyebabkan berkembangnya penelitian mengenai obat-obat tradisional dalam bidang kesehatan. Salah satu tanaman yang bermanfaat dalam bidang kesehatan ialah tanaman pirdot. Pirdot merupakan tanaman liar yang tumbuh di tempat lembab/teduh. Menurut jurnal penelitian (Lumban Gaol, 2016) ekstrak etanol daun pirdot yang diekstraksi dengan cara maserasi memiliki aktivitas antidiabetes dan diperoleh bahwa daun pirdot mengandung bebeberapa metabolit sekunder seperti flavonoid, glikosida, steroid/triterpenoid, saponin dan tanin.

Senyawa fenol dan turunannya (flavonoid) merupakan salah satu antibakteri yang bekerja dengan mengganggu fungsi membran sitoplasma. Daun pirdot secara tradisional memiliki khasiat untuk mengobati banyak penyakit (Barus, 2018).

Melihat potensi tanaman pirdot sebagai tanaman obat, maka perlu dilakukan karakterisasi simplisia dan standardisasi ekstrak daun pirdot sehingga dapat menetapkan mutu dan keamanan bahan bahan baku ekstrak yang digunakan dalam menunjang kesehatan. Pengujian standardisasi ini dilakukan pada ekstraksi daun pirdot dengan menggunakan pelarut etanol.

Etanol merupakan pelarut serba guna yang baik untuk ekstraksi pendahuluan (Harbone, 1987). Berdasarkan uraian di atas, tujuan penelitian ini adalah membuktikan adanya aktivitas antibakteri ekstrak etanol daun pirdot (EEDP) terhadap pertumbuhan Salmonella typhy)

\section{METODE PENELITIAN Jenis Penelitian}

Penelitian ini bersifat experiment laboratories secara in vitro untuk menguji aktivitas antibakteri daun pirdot terhadap bakteri Salmonella typhi. 


\section{Tempat dan Waktu Penelitian}

Penelitian ini dilaksanakan di Laboratorium Kimia Kualitatif, Biologi dan Mikrobiologi Institut Kesehatan Medistra Lubuk Pakam. Penelitian ini dilaksanakan pada bulan Februari- Juli 2019

\section{Bahan}

Daun Pirdot yang diperoleh dari Desa Lumban Tanjung 2 Kecamatan Nagasaribu Kabupaten Humbang Hasundutan Sumatera Utara, biakan murni bakteri Salmonella typhi yang diperoleh dari Laboratorium Mikrobiologi Rumah Sakit Grandmed Lubuk Pakam Sumatera Utara, medium Nutrient Agar (NA), $\mathrm{NaCl} 0.9 \%$, etanol $96 \%$ dan zat antibiotik kloramfenikol, aquadest, alfa naftol, amil alkohol, asam asetat anhidridat, asam klorida pekat, asam nitrat pekat, asam sulfat pekat, besi (III) klorida, bismuth nitrat, kalium iodida, kloroform, natrium hidroksida, kloralhidrat, serbuk magnesium, iodium, raksa (II) klorida, timbal (II) asetat dan toluen.

\section{Alat}

Erlenmeyer $500 \mathrm{~mL}$, gelas ukur $500 \mathrm{~mL}$ dan $100 \mathrm{~mL}$, aluminium foil, neraca analitik, 6 tabung reaksi, 18 cawan petri, hot plate, laminar air flow, gelas piala $500 \mathrm{ml}$ dan $100 \mathrm{ml}$, lampu bunsen, jarum ose, autoklaf, lemari pendingin, mortar dan stamper, rak tabung, korek api, kapas steril, kertas label, gunting, kertas perkamen, spatula, pinset, pisau, rotary evaporator, oven, jangka sorong, cakram kertas jenis Kirby Bauerdengan diameter $6 \mathrm{~mm}$, tissue, inkubator, kamera, sarung tangan, mikropipet (10-1000 $\mu \mathrm{L})$, masker dan penutup kepala.

\section{Prosedur Kerja}

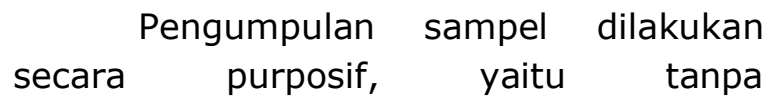

membandingkan dengan sampel yang sama dari daerah lain yang diambil dari Desa Lumban tanjung 2 Kecamatan Nagasaribu Kabupaten Humbang Hasundutan Sumatera Utara. Bagian tumbuhan yang diambil adalah bagian daun yang tua. Daun dibersihkan dari kotoran yang menempel lalu dikeringkan yang selanjutnya akan dibuat untuk pembuatan ekstrak daun pirdot.

Pembuatan ekstrak etanol daun pirdot (EEDP) dengan metode maserasi dengan pelarut etanol $96 \%$. Sebanyak 500 gram daun pirdot yang telah dikeringkan lalu diblender hingga menjadi serbuk halus lalu direndam dengan etanol 96\% sebanyak 5 liter dan didiamkan didalamtoples selama 5 hari ditempat yang terlindung dari cahaya langsung. Selanjutnya disaring, hasil saringan atau filtrate cair ekstrak etanol daun pirdot diuapkan menggunakan rotary evaporator untuk mendapatkan ekstrak etanol kental daun pirdot.

Pemeriksaan kandungan metabolit sekunder dengan skrining fitokimia terhadap serbuk simplisia dan EEDP, meliputi pemeriksaan glikosida, flavonoid, saponin, tanin dan steroid (Kaban,2018).

Metode yang digunakan dalam penelitian ini adalah metode Kirby Bauer, yaitu metode difusi dengan cakram kertas. Medium NA dituang kecawan petri sebanyak $10 \mathrm{~mL}$, masing-masing bakteri Salmonella typhi sebagai biakan uji, dipipet dari medium larutan $\mathrm{NaCl} 0.9 \%$ ke 6 cawan petri steril masing-masing sebanyak $200 \mu \mathrm{l}$. Cawan petri kemudian digoyang secara perlahan-lahan untuk menyebarkan biakan bakteri secara merata dan didiamkan hingga medium memadat. Masing-masing dari cakram kertas steril dipindahkan secara aseptik menggunakan pinset steril ke konsentrasi yakni, blanko (DMSO), $50 \mathrm{mg} / \mathrm{ml}, 100$ $\mathrm{mg} / \mathrm{ml}, 150 \mathrm{mg} / \mathrm{ml}, 200 \mathrm{mg} / \mathrm{ml}$ (Tangapo, 
Received: 05 September 2019 :: Accepted: 14 September 2019 :: Published: 31 Oktober 2019

2005). Cakram kertas yang telah direndam dengan ekstrak etanol daun pirdot dipindahkan dengan pinset steril ke medium NA yang sudah berisi bakteri Salmonella typhi secara aseptik, kemudian diinkubasi selama $1 \times 24$ jam dengan suhu $37^{\circ} \mathrm{C}$. Setelah diinkubasi, diamati zona bening yang terdapat disekitar kertas cakram dan diukur diameternya menggunakan jangka sorong (Tangapo, 2005).

\section{HASIL DAN PEMBAHASAN}

Ekstrak kental yang diperoleh dari hasil ekstraksi sebanyak 98 gram.

Hasil pemeriksaan kandungan metabolit sekunder dengan skrining fitokimia terhadap serbuk simplisia dan EEDP, meliputi pemeriksaan glikosida, flavonoid, saponin, tanin dan steroid dapat dilihat dari tabel berikut:

\begin{tabular}{|l|c|c|}
\hline $\begin{array}{l}\text { Senyawa } \\
\text { Metabolit } \\
\text { Sekunder }\end{array}$ & $\begin{array}{c}\text { Serbuk } \\
\text { Daun } \\
\text { Pirdot }\end{array}$ & $\begin{array}{c}\text { Ekstrak } \\
\text { Etanol Daun } \\
\text { Pirdot } \\
\text { (EEDP) }\end{array}$ \\
\hline Flavonoid & + & + \\
\hline Tannin & + & + \\
\hline Saponin & + & + \\
\hline Glikosida & - & - \\
\hline Alkaloid & + & + \\
\hline \multicolumn{1}{|r|}{ Tabel } & Hasil skrining fitokimia \\
\hline
\end{tabular}

Tabel 1. Hasil skrining fitokimia serbuk daun pirdot dan ekstrak EEDP.

Keterangan $(+)=$ menunjukkan bahwa serbuk daun pirdot dan ekstrak etanol $96 \%$ daun pirdot memiliki metabolit sekunder: flavonoid, tannin, sapoin dan alkaloid.

Hasil pengujian antibakteri ekstrak dilakukan tiga kali pengulangan dan memperoleh hasil rata-rata, pada konsentrasi $50 \mathrm{mg} / \mathrm{ml}$ mempunyai zona hambat sebesar $14.45 \mathrm{~mm}$, pada konsentrasi $100 \mathrm{mg} / \mathrm{ml}$ mempunyai zona hambat sebesar $16.54 \mathrm{~mm}$, pada konsentrasi $150 \mathrm{mg} / \mathrm{ml}$ mempunyai zona hambat sebesar $18.66 \mathrm{~mm}$, pada konsentrasi $200 \mathrm{mg} / \mathrm{ml}$ mempunyai zona hambat sebesar $20.78 \mathrm{~mm}$ dan Blanko (DMSO) tidak menunjukkan adanya daya hambat terhadap bakteri.

Dapat dilihat pada Tabel. 1 dibawah ini:

\begin{tabular}{|l|c|}
\hline $\begin{array}{c}\text { Konsentrasi } \\
\text { Ekstrak } \\
\text { Etanol Daun } \\
\text { Pirdot (EEDP) }\end{array}$ & $\begin{array}{c}\text { Rata-Rata } \\
\text { Diameter } \\
\text { Zona Hambat } \\
\text { (mm) }\end{array}$ \\
\hline DMSO & - \\
\hline $50 \mathrm{mg} / \mathrm{ml}$ & 14.45 \\
\hline $100 \mathrm{mg} / \mathrm{ml}$ & 16.54 \\
\hline $150 \mathrm{mg} / \mathrm{ml}$ & 18.66 \\
\hline $200 \mathrm{mg} / \mathrm{ml}$ & 20.78 \\
\hline Tabel 2. Hasil uji diameter zona
\end{tabular}

hambat $(\mathrm{mm})$ daun pirdot terhadap pertumbuhan terhadap bakteri Salmonella typhi

Dari hasil keempat ekstrak baik konsentrasi $50 \mathrm{mg} / \mathrm{ml}, 100 \mathrm{mg} / \mathrm{ml}, 150$ $\mathrm{mg} / \mathrm{ml}$ dan $200 \mathrm{mg} / \mathrm{ml}$ ternyata hasilnya memenuhi standar dari Ditjen POM (1995) yaitu suatu sediaan atau ekstrak dikatakan memiliki daya hambat bakteri jika memenuhi persyaratan dengan diameter daerah hambatan lebih kurang 14 sampai $16 \mathrm{~mm}$.

\section{KESIMPULAN}

Hasil penelitian yang dilakukan terhadap ekstrak etanol daun pirdot (EEDP) maka diperoleh kesimpulan:

1. Kandungan senyawa kimia yang terdapat pada daun pirdot ialah flavonoid, tanin, saponin, dan alkaloid

2. Ekstrak EEDP memiliki aktivitas antibakteri terhadap bakteri Salmonella typhi. Ekstrak dengan konsentrasi $50 \mathrm{mg} / \mathrm{ml}$ mempunyai zona hambat sebesar $14.45 \mathrm{~mm}$, konsentrasi $100 \mathrm{mg} / \mathrm{ml}$ ekstrak mempunyai zona hambat sebesar $16.54 \mathrm{~mm}$, konsentrasi $150 \mathrm{mg} / \mathrm{ml}$ 
ekstrak mempunyai zona hambat sebesar $18.66 \mathrm{~mm}$ dan pada konsentrasi $200 \mathrm{mg} / \mathrm{ml}$ mempunyai zona hambat sebesar $20.78 \mathrm{~mm}$.

3. Dan hasil keempat ekstrak etanol daun pirdot baik konsentrasi 50 $\mathrm{mg} / \mathrm{ml}, 100 \mathrm{mg} / \mathrm{ml}, 150 \mathrm{mg} / \mathrm{ml}$ dan $200 \mathrm{mg} / \mathrm{ml}$ memenuhi standar dari Ditjen POM (1995) yaitu suatu sediaan atau ekstrak dikatakan memiliki daya hambat bakteri jika memenuhi persyaratan dengan diameter daerah hambatan lebih kurang 14 sampai $16 \mathrm{~mm}$

\section{SARAN}

\section{Saran Untuk Institusi}

Diharapkan bahwa penelitian ini dapat dikembangkan menjadi bahan pembelajaran dan bahan referensi bacaan untuk pegembangan penelitian dalam bidang obat tradisional.

\section{Saran Untuk Peneliti Selanjutnya}

Untuk peneliti selanjutnya disarankan untuk memperhatikan daerah tumbuh dari daun pirdot yang akan dijadikan sampel penelitian dan membuat formulasi dari ekstrak daun pirdot.

\section{DAFTAR PUSTAKA}

Barus, B., \& Lestari, I. (2018). Pengaruh Ekstrak Umbi Bawang Putih Dan Umbi Bawang Merah Terhadap Luka Bakar Pada Kelinci. Jurnal Farmasimed (JFM), 1(1), 1-5. https://doi.org/10.35451/jfm.v1i 1.86

Depkes RI. (2013). Riset Kesehatan Dasar. Jakarta: Badan Penelitian dan Pengembangan Kesehatan Kementrian Kesehatan RI.

Ditjen POM. (2000). Farmakope Indonesia Edisi ke III. Jakarta: Departemen Kesehatan Republik Indonesia. Halaman 748.
Ditjen POM.

(1995).

Farmakope Indonesia. Edisi IV. Jakarta: Departemen Kesehatan Republik Indonesia. Halaman 1083-1084.

Garna, H. H. (2012). Divisi Infeksi Dan Penyakit Tropis Departemen Ilmu Kesehatan Anak Fakultas Kedokteran Universitas Padjajaran/RSUP DR.Hasan Sadikin Bandung. Jakarta: Sagung Seto.

Harborne, J.B. (1987). Metode Fitokimia, Penuntun Cara Modern Menganalisa Tumbuhan. Terjemahan Kosasih Padmawinata. Edisi II. Bandung: ITB Press. Hal.69, 102-103, 147149, 234.

Lumban Gaol, Eva. (2016). Uji Aktivitas Antibakteri Dari Ekstrak Daun Pirdot terhadap bakteri Escherichia coli

Tangapo. A. M. 2005. Efektivitas Antibakteri Ekstrak Tumbuhan Daun Sendok (Plantago major) terhadap Staphylococcus aureus dan Pseudomonas eruginosa [Skripsi]. Universitas Sam Ratulangi. Manado

WHO (2003).The International Pharmacopoeia. Sixth Edition. Electronic Version Geneva.World Health Organization.

Kaban, V., \& Yusmarlisa, S. (2018). Uji Aktivitas Kandungan Antioksidan Pada Daun Bangun-Bangun (Plectranthus amboinicus) Secara Spektrofotometri UltravioletVisible. JURNAL FARMASIMED (JFM), 1(1), 16-20. https://doi.org/10.35451/jfm.v1i 1.90

Widodo. (2009). Pemberian Makanan, Suplemen dan Obat pada Anak. Jakarta: EGC 
Jurnal Farmasi, e-ISSN: 2655-0814

Vol. 2 No.1 Edisi Mei-Oktober 2019

http://ejournal.medistra.ac.id/index.php/JFM

Received: 05 September 2019 :: Accepted: 14 September 2019 :: Published: 31 Oktober 2019 